\title{
The first School of Nursing Education in Greece
}

\section{Lambrini Kourkouta $^{1}$, Ioanna Papathanasiou ${ }^{2}$, Paraskevi Georgoysi ${ }^{3}$}

${ }^{1}$ Nursing Department, Technological Educational Institute of Thessaloniki, Greece. ${ }^{2}$ Nursing Department, Technological Educational Institute of Larissa, Greece. ${ }^{3}$ Nursing Department, Technological Educational Institute of Patra, Greece

\section{ARTICLE INFO}

Received

Accepted

Published

$: 20 / 02 / 2012$

: 07/05/2012

$: 01 / 12 / 2012$

\section{KEYWORD}

Nursing education

Military school

Nursing specialty

History of Greece

\section{ABSTRACT}

The first School of Nursing Education in Greece was military and was found on August $18^{\text {th }}, 1861$. Its purpose was to educate soldiers as experienced nurses for times of peace and war. Those soldiers, who successfully enrolled in this school, acquired the nursing specialty and were used as such, their specialty being noted on the certificate after their dismissal from the army. The fact that they were chosen from the very best of the soldiers and also that they had to be literate shows that the interest of the state was to have good and well educated nurses.

CORRESPONDING AUTHOR: Prof. Lambrini Kourkouta, Diocharous 17, Athens 16121, Greece

Tel: 003 21014018603, e-mail: laku1964@yahoo.gr 


\section{Introduction}

After the liberation of Greece from the Ottomans, who were in possession for 400 years, the provision of health services to residents of the strife-torn country was one of the priorities of the new authorities of the state $[1,2]$. So with the Royal Decree (R.D.) of the $3^{\text {rd }}$ of April 1833, a University (picture 1) with four faculties was established, including a Medical School [3, 4]. The first public building which was built in the Greek state was the Military Hospital (picture 2) in "Makriyannis" [5, 6]. This was where generations of health care professionals, medical and nursing students were trained [7, 8]. The successful supply and application of medical services to hospitalized soldiers and other citizens, depended on the care provided by highly trained physicians working together with responsible and well educated nursing staff [9, 10].The aim of this historical study is to present how the Directorate of Health Care Services of the Greek Army established the first School of Nursing Education in the then troubled Greece.

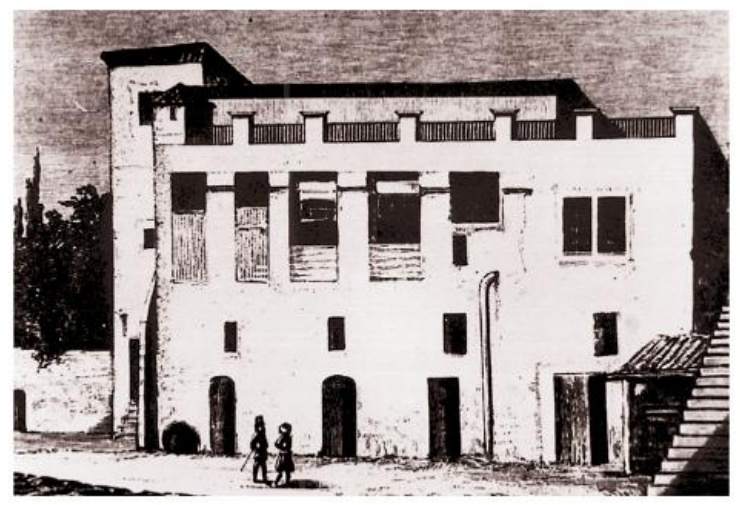

Picture 1: The First University of Greece

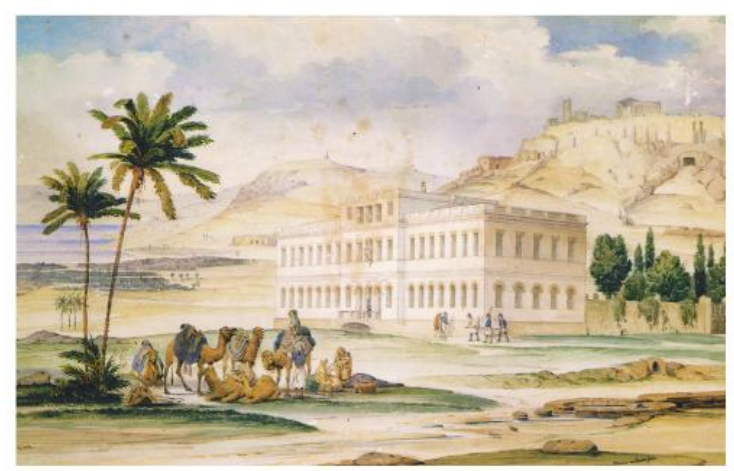

Picture 2: The First Military Hospital in "Makriyiannis"

\section{Method and Material}

The methodology of historical research was used to conduct this study. Source of data were the Laws and Decrees of the time, and publications such as articles, studies, documents and photographs on this matter. A system of classification of data by source, in alphabetical and chronological order was used for the archiving of the material.

\section{Organizing health care services in Greece}

The first essential organization of health care services in Greece was during the Ottoman period (1833-1862) governance of the newly established country [1,2]. The Bavarians and the few doctors philhellenes fighters who remained in Greece were the first members of the health department which was dominated by Henry Traimper (1796-1882), who was the organizer and first commander [3, 11]. According to the above, the Directorate of Health Services of the Greek Army established the first "School of Nurses" with the Royal Degree which was called "Establishment of a Nursing School" on $18^{\text {th }}$ of August 1861 [12]. This action shows how well organized and reliable the Health Services of the Greek Army were at the time [11]. Gradually, the Health Service was staffed by Greek citizens, while it was developed and organized, creating small regional hospitals and clinics, to meet the needs of the Greek people [5]. Physicians also began to publish regularly in the international medical press reports on the health situation of the country, which showed that the various indicators of morbidity and mortality were similar to those of the advanced countries of that time $[3,11]$.

\section{Foundation of the First Nursing School in Greece}

One of the most important moments in the history of health of Greece of that time was the establishment of the "Nursing School" on August 18, 1861 [9]. The foundation of this school was almost made simultaneously with the establishment of the Nursing School of Florence 
Nightingale in Saint Thomas hospital in London (1860) [10,13].

\section{Royal Decree establishing a "Nursing School"}

After the Minister of Defense's proposal the following was decided [12]:

1. The establishment of a Nursing School in Athens, whose purpose was to educate experienced nurses, capable of servicing in times of peace and war.

2. The highest in rank supervision of that school was appointed to the Head physician of the army. For the students' education this Head physician could use one or more lower health providers, who were appointed by the Minister of Defense.

3. All the services that were provided by the Headmaster and the lower officers were voluntary.

4. The education of the nursing students was done in a specially designed ward of the hospital of Athens, twice a year, both winter and summer, during the period stipulated by the Minister of Defense. Each training period lasted two months.

5. The education of Nursing Students combined theory and practice in the following subjects:

a) Basic knowledge of Anatomy and Physiology.

b) Basic knowledge of Epidemiology.

c) First Aid to the injured.

d) Nursing tasks in times of battle, such as finding the wounded and various methods of moving them.

e) Elementary knowledge of surgical performance.

f) First aid to the injured from suffocation provoked by various reasons.

g) Nursing tasks within the area of the hospital and within various sanatoriums.

h) Nursing tasks for the deceased.

The Minister of Defense, in accordance with the relevant provision, issued a decree, which was named "Training of Nurses" and with which the curriculum of the above teaching subjects was determined.

6. In each group of ten battalions of infantry there had to be at least two male trainee nurses at all times. Half of all the male trainee nurses had to be sent to the School of Nursing during the summer and the rest during the winter, so that everyone was taught the nursing duties in detail once a year.

7. It is best only trained nurses to work in the hospitals and sanatoriums and only in cases of emergency (when the trained nurses are not sufficient) can other soldiers be used as nursing staff.

8. At the end of the summer and winter teaching period, the graduate nurses returned to the army, specifically to the military hospitals or clinics to replace those already serving in them, who in the next training period of the school, were sent to Athens to be trained.

9. Soldiers who were selected and that wanted to be trained as nurses had to have excellent behavior, knowledge, literacy, or at least had to be able to read. The selected soldiers were obliged to remain in the active army for two more years.

10. Once the summer and winter session was over, nurses underwent tests and those who excelled were given useful items as prizes by the Minister of Defense for their nursing careers. Finally, the army certificate, for the soldiers who were trained as nurses, noted "Educated for Nursing Tasks". With this certificate, after their discharge from the army, they could get a practicing license, with which they could work as nurses in the public and private hospitals and clinics.

11. The execution of this decree was undertaken by the Minister of Defense.

Athens, $18^{\text {th }}$ of August, 1861 In the name of the King The Queen Amalia (Picture 3).

The Great Military and Naval Encyclopedia states: "The school was established on the $18^{\text {th }}$ of August in order to educate experienced nurses to work in times of need. The soldiers who will graduate from this nursing school will gain the nursing specialty and can be used as such. This nursing specialty must be noted on the army certificate on their dismissal" [14]. As said the 
establishment of "School of Nurses" in the Greek army shows not only the extent of scientific training of Greek health officers, but also the sense of responsibility that they had.

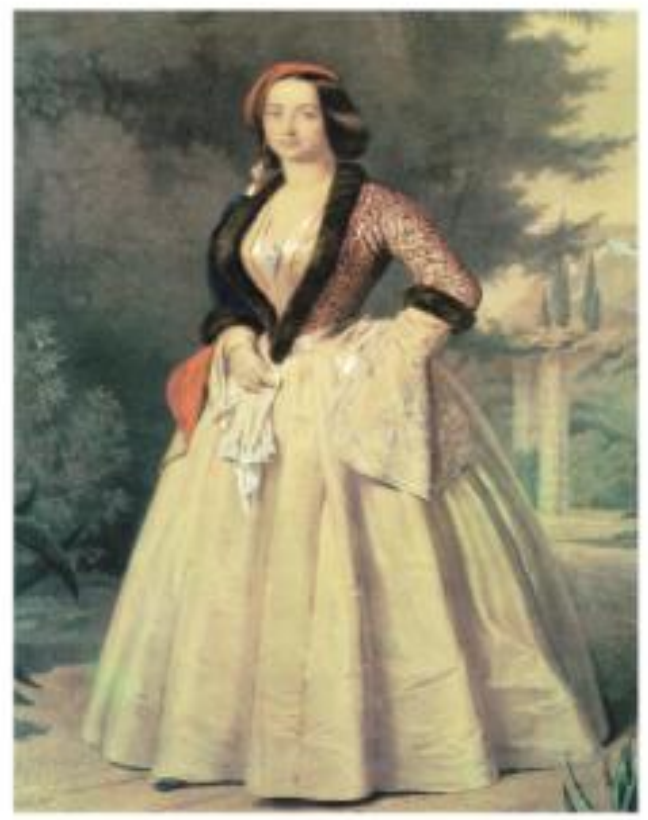

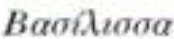

Apatia.

Picture 3: Queen Amalia

The fact that nurses-soldiers (picture 4, 5) were chosen from the very best of the soldiers and also that they had to be literate shows that the interest of the state was to have good and well educated nurses. There were very few illiterate soldiers one hundred and fifty years ago and they were considered to be educated for their time [15]. With various decrees that were issued later the number of nurses was defined to three hundred, who were divided into two battalions. These two battalions had a stable number of men in all subsequent restructuring of the army until the war of 1897 [16, 17]. During the conscription of all citizens of 1897 the number of soldiersnurses increased. The $20^{\text {th }}$ battalion consisting of four officers and 234 soldiers- nurses, for which there is evidence, served in the army of Central Greece (Thessaly) During the Balkan Wars the nurses increased to three battalions $[16,18]$. It is finally mentioned that also the nurses - soldiers bore gun. In the "Greek-Turkish war" of 1897 for example, the nurses' weapon was the shotgun "Gra".

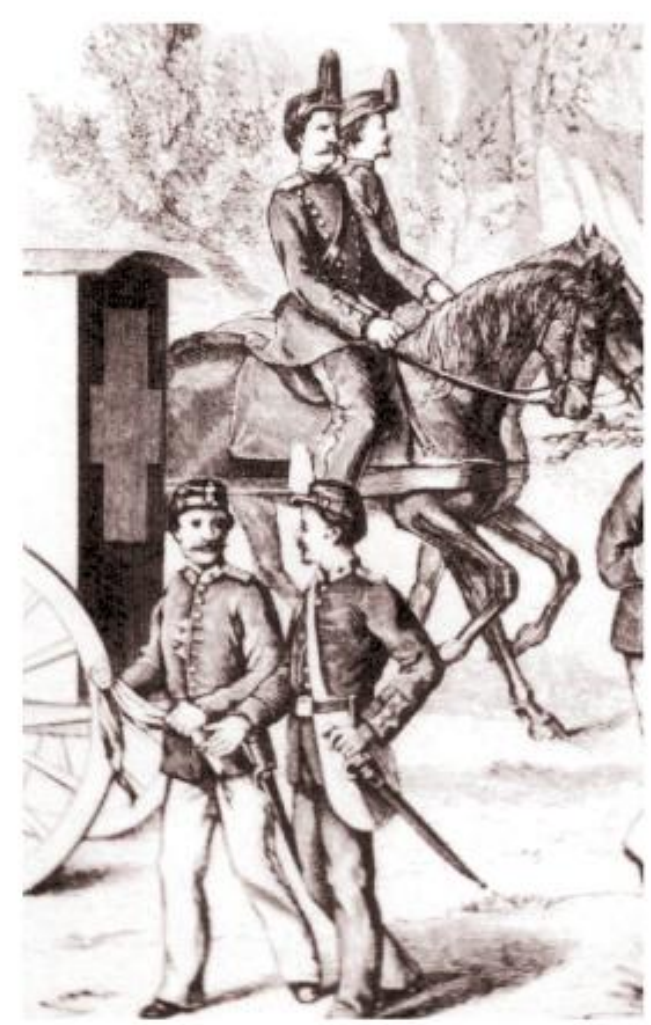

Picture 4: Nurses-Soldiers of the Greek Army

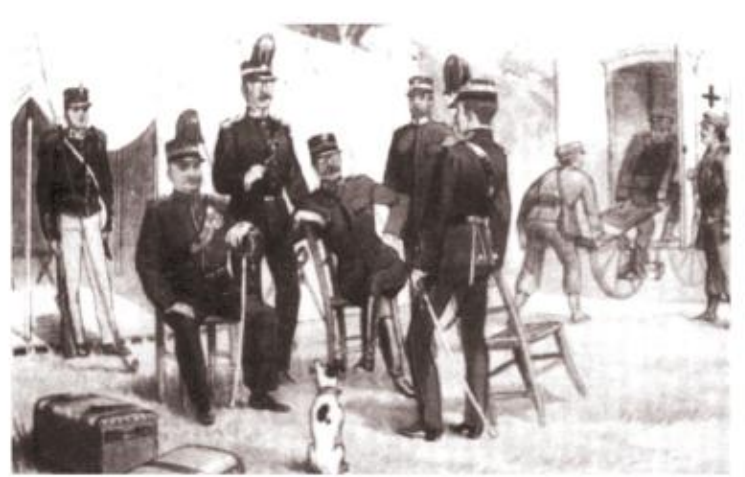

Picture 5: Officers and nurses of Health Department of the Greek Army

In this particular war the nurses-soldiers used as a weapon their soul, fulfilling their duty to Asclepius. All the doctors and nurses from the Hygiene Department of the army took part in that war and two of them were killed. They were Verginis Athanasius from Kalamitsi Corfu and Tsamis Dimitrius from Mandra Attiki [11, 21]. Nurses as well as doctors offered their services in the battle field, in military hospitals, in trains, ships and other transports and in any services they were needed. Their lives were at a risk. In addition many nurses-soldiers were killed in other wars, such as the "Asia Minor 
Catastrophe" of 1922 and in the $2^{\text {nd }}$ World War in 1940-41.In Greek history many acts of heroism and self-sacrifice of nurses and doctors are recorded. These actions inspire the younger generations of Greek nurses.

\section{Conclusion}

The provision of health services therefore, was one of the priorities of the governments of the newly created state, to the suffering people, after the hardships of the liberation struggle. Under this policy was the systematic and perfect organization of the various departments and sectors of the then Health Service, which included innovative practice and creation of the "School of Nurses", so steadily gaining recognition in the Greek society. Besides the protection of the health of citizens, especially soldiers, who form the backbone of a country, means healthy citizens, able to help their country develop in every field of activity, which enables it to meet the obligations, both locally and internationally.

\section{Reference}

1. Kokkinou DA. History of Modern Greece. Volume:1-4. Melissa Athens; 1972.

2. Markazini SB. Political History of Modern Greece. Papyrus Athens; 1966.

3. Laskaratos IC. History of Medicine. Paschalidis; 2004.

4. Royal Decree "Establishing a University and a College." Encyclopedia Larousse Britannica. Athens; 1991.

5. Kourkouta L. Nursing Institutes of Greece, especially of Athens and Piraeus, in the $19^{\text {th }}$ century. Nosileftiki. 1996; 4:254-261.

6. Biri KM. Athens. Second Edition. Melissa Athens; 1995.

7. Papadimitrakopoulos H. The hospital Makriyannis. Kathimerini. 1991;1-20.

8. Louros N. Flashbacks. Parisianos Athens; 1967.

9. Kourkouta L., et al. The First School of Nurses in Greece. $35^{\text {th }}$ Pan-Hellenic Nursing Conference. Volume of Abstracts. Athens; 2008.
10. Lanara BA. One Hundred Years of the Nursing School of Evaggelismos (18751975). National Editions. Athens; 1978.

11. Royal Decree. The establishment of a Nursing School. Asclepius. 1861; 6:46.

12. Vladimiros LE. The health department in Greek-Turkish War of 1897. Logothetis Athens; 1997.

13. Messolora AJ. A brief History of the evolution of nursing in Greece.Translation by IH Charley. A publication of Hellenic Red Cross. Athens; 1967.

14. Anonymos. Military organization of Greece. Great Military and Naval Encyclopedia. $3^{\text {rd }}$ Vol. Athens; 1929.

15. Kourkouta L. History of Nursing. Paschalidis; 2010.

16. Grigoras DG. History of Military Medicine in Greece. Scientific Union of Army Forces. Athens; 2000.

17. Geroulanos M. Memories (1867-1957). Pages from the history of Modern medicine in Greece. Kastaniotis Athens; 1995.

18. Diamantis GA. History of Military Medicine and Nursing in Greece. Lege Artir, Athens; 2004.

19. Kourkouta L, et al. Nurses in Greek-Turkish War of 1897. 34 ${ }^{\text {th }}$ Pan-Hellenic Nursing Conference. Volume of Abstracts. Athens; 2008.

20. Kourkouta L, et al. Queen Olga. The "Lady" of the Greek Nursing. 33rd Pan-Hellenic Medical Congress. Volume of Abstracts. Athens; 2008.

21. War Department. Fights and Dead 1830 1930. $1^{\text {st }}$ Volume. Athens; 1930. 